\title{
液膜の滞留位置に気流の及ぼす影響* （水平円板間に噴霧流を吹き込む場合に関連して）
}

\author{
村上 幸 一*1, 野村 信 福*1, 田谷敏 宏*2
}

\author{
Effect of Air Flow on Position of Standing Liquid Film \\ (In Connection with Mist Flow Injected between Horizontal Disks)
}

\author{
Koichi MURAKAMI, Sinfuku NOMURA and Toshihiro TADANI
}

\begin{abstract}
When mist flow is injected from a jointed pipe vertically between horizontal parallel disks, a liquid film is standing at the specific position on the lower disk. The position of standing liquid film is concerned with the flow between disks. The numerical calculation is performed on the flow using low-Reynolds-number $k-\varepsilon$ model. As a result, in the direction of downstream from the position of maximum of pressure gradient on the lower disk, the condition of the flow near the disk changes and intensity of turbulence begins to increase. Comparing with the position of standing liquid film, it is greatly concerned with the condition of the flow near the lower disk.
\end{abstract}

Key Words : Numerical Calculation, Turbulent flow, Liquid Film, Standing Position, Horizontal Parallel Disks

\section{1. 緒言}

プラント等の長年にわたり噴霧流が流し続けられる 管路では，その曲がり部に気流中の液滴が付着し，不 純物が析出し管路壁が腐食する。このような事態を避 けるためには，管路曲がり部での噴霧流の流れや管路 壁に付着する液滴や液膜について知ることが重要であ る.

これまで,このような現象のモデルとして水平な平 行円板間に上方円板の中心汃ら噴霧流を吹き込んだ場 合を想定し実験的に研究してきた ${ }^{(1)}$. 円板間に吹き込 まれた噴霧流は，下方円板に衝突する小さな液滴の状 態では中心近傍にとどまるが，合体し大きな液滴や液 膜になると下方円板上の特定の位置に滞留する．この 特定位置近傍で下方円板上の流れが大きく変化してい ることがわかっている。

そこで, 本研究では円板間隔を変化させた場合に

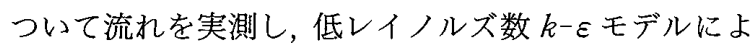
る数值解析との比較検討から, 円板間隔の違いが気流

* 原稿受付 1997 年 9 月 19 日.

*1 正員, 愛媛大学工学部( 790-8577 松山市文京町 3).

*2 高砂熱学(画812-0011 福岡市博多区博多駅前 2-3-7).
の流れに及ぼす影響を示し，下方円板近傍の流れの状 態と液膜の滞留位置の関係について検討する。

\section{おもな 記 号}

$b$ : 半值幅 $\mathrm{mm}$

$C_{\varepsilon 1}, C_{\varepsilon 2}, C_{\mu}: k-\varepsilon$ モデルのモデル定数

$d n$ :円管内径 $\mathrm{mm}$

$f_{1}, f_{2}, f_{\mu}: k-\varepsilon$ モデルのモデル関数

$G$ : 乱流エネルギー方程式の応力による生成項

$h:$ 液滴の高さ $\mathrm{mm}$

$H$ : 円板間隔 $\mathrm{mm}$

$k:$ 乱流エネルギー $(\mathrm{m} / \mathrm{s})^{2}$

$p:$ 圧力 $\mathrm{Pa}$

$r:$ 円板中心からの半径方向距離 $\mathrm{mm}$

$r_{b}$ : 円板近傍流れの状態が変化する位置 $\mathrm{mm}$

$r_{c}:$ 円管流出口の丸み半径 $\mathrm{mm}$

$r_{p}:$ 下方円板上の圧力こう配が最大となる位置 $\mathrm{mm}$

$r_{R}$ : 下方円板上の液滴の滞留位置 $\mathrm{mm}$

$r_{t}$ : 上方円板上の流れの付着位置 $\mathrm{mm}$

$R:$ 円板半径 $\mathrm{mm}$

$u, v: r$ 方向, $z$ 方向の速度 $\mathrm{m} / \mathrm{s}$

$u^{+}$: 無次元速度 $=u / u_{\tau}$ 
$u_{\varepsilon}:$ コルモゴロフの速度スケール $=(\nu \varepsilon)^{1 / 4}$

$\mathrm{m} / \mathrm{s}$

$u_{\tau}, v_{\tau}$ : 摩擦速度 $\mathrm{m} / \mathrm{s}$

$v_{a}:$ 円管内の平均速度 $\mathrm{m} / \mathrm{s}$

$V:$ 液滴の体積 $\mathrm{cc}$

$y^{+}, y^{*}$ : 無次元壁面高さ $u_{\tau} y / \nu$ または $v_{\tau} y / \nu, u_{\varepsilon} y / \nu$

$z$ :下方円板からの高さ $\mathrm{mm}$

$z_{m}:$ 速度 $u$ が最大となる高さ $\mathrm{mm}$

$\varepsilon:$ 乱流エネルギーの散逸率 $\mathrm{m}^{2} / \mathrm{s}^{3}$

$\varkappa$ : カルマン定数 $(=0.41)$

$\nu$ : 動粘性係数 $\mathrm{m}^{2} / \mathrm{s}$

$\nu_{t}$ : 渦動粘性係数 $\mathrm{m}^{2} / \mathrm{s}$

$\rho_{g}:$ 空気の密度 $\mathrm{kg} / \mathrm{m}^{3}$

上添字*：無次元值を表す

\section{2. 解 析 方 法}

$2 \cdot 1$ 平行円板間に吹き込む流れの解析 既報(1) の円板間へ吹き込む空気流量に対する液流量の体積比 は, 最大でも $3 \times 10^{-5}$ と小さいので, 気体のみの単相 流とする。また，合体した液滴が下方円板上の特定位 置に滞留し円周方向に大きく成長するまでは, 液の円 板上に占める面積は少ないので, 液滴や液膜は流れに 影響しないと仮定する。

本研究の流れは水平な平行円板間に円管から吹き込 まれた気流が下方円板に衝突し，下方円板に沿って放 射状に流れ，上方円板への再付着を伴う複雑な衝突噴 流である。このような流れと熱伝達に関する研究は数 多く見られるが, 数値解析による乱流場の模擬につい ては，まだ問願点が多い. Looney ら (2) は高レイノル ズ数 $k-\varepsilon モ テ ゙ ル^{(3)}($ High) を使用して, スリットノズ ル幅 $d n$ と平板間隔 $H$ の比 $H / d n$ が 22 の流れ場を解 析しているが，間隔比が大きいこの場合実際の流れを 模擬できている.しかし, Hosseinalipour ら(4) はス リットノズルについて, 間隔比 $H / d n$ が 1.5 の場合に ついて High モデルといくつかの低レイノルズ数 $k-\varepsilon$ モデルを使用して解析を行っているが, 実際の流れを あまり模擬できていない.

壁面近傍の挙動までよく模擬できる壁面で $\varepsilon を$ 零 としない低レイノルズ数 $k-\varepsilon$ モデルが, 明・笠木 ${ }^{(5)}$ $(\mathrm{MK})$, Abe-Kondoh-Nagano(6) $(\mathrm{AKN})$ によって提 案されている. MK モデルではモデル関数 $f_{\mu}$ の中の $y^{+}$が本研究のような再付着を伴う流れでは, 再付着 点で $y^{+}=0$ となるために不都合が起きるが, AKN モ デルではコルモゴロフの速度スケール $u_{\varepsilon}\left[=(\nu \varepsilon)^{1 / 4}\right]$ で定義された $y^{*}\left(=u_{\varepsilon} y / \nu\right)$ をモデル関数として使用す ることで, 再付着点でも $u_{\varepsilon}$ は有限な值をもつために

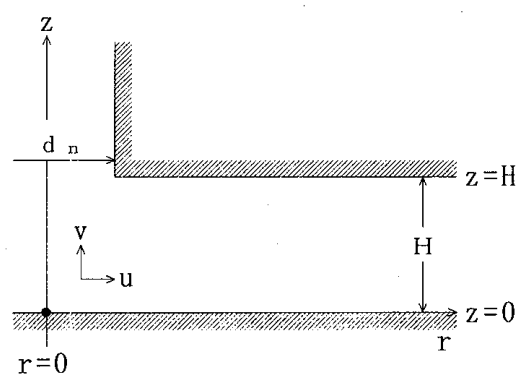

Fig. 1 Flow configuration and coordinate system

再付着流れの計算に適している。そこで, 本研究では， $\mathrm{AKN}$ モデルを用いる。

$2 \cdot 2$ 解析系と基礎式 図 1 に解析対象とする流 れ場の概要と座標系を示す. 間隔 $H$ の平行円板の上 方円板に内径 $d n$ の円管が垂直に接続している。な お，円管内の平均速度は $v_{a}$ とする. 解析は間隔比 $H / d n=0.32,0.5,0.64,1.004$ 種, 二次元, 定常, 非 圧縮性流体として行う。基礎方程式として, 連続の式 (1)，ナビエ・ストークスの式(2)，(3)，乱流エネ ルギー $k$ の方程式 $(4)$, 乱流エネルギ一の散逸率 $\varepsilon$ の

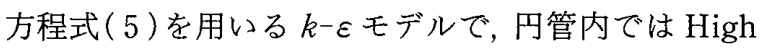
モデル，円板間では出口に近づくにつれ代表長さを $H$ とする $R e$ 数が減少し, 層流に近い場合もあるので AKN モデルを使用する.

$$
\begin{aligned}
& \frac{\partial}{\partial r}(r u)+\frac{\partial}{\partial z}(r v)=0 \\
& \frac{\partial}{\partial r}\left[r\left\{u^{2}-\left(\nu+\nu_{t}\right) \frac{\partial u}{\partial r}\right\}\right] \\
& +\frac{\partial}{\partial z}\left[r\left\{u v-\left(\nu+\nu_{t}\right) \frac{\partial u}{\partial z}\right\}\right] \\
& =-\frac{r}{\rho_{g}} \frac{\partial p}{\partial r}+\frac{\partial}{\partial r}\left\{r\left(\nu+\nu_{t}\right) \frac{\partial u}{\partial r}\right\} \\
& +\frac{\partial}{\partial z}\left\{r\left(\nu+\nu_{t}\right) \frac{\partial v}{\partial r}\right\}-2\left(\nu+\nu_{t}\right) \frac{u}{r} \text {. } \\
& \frac{\partial}{\partial r}\left[r\left\{u v-\left(\nu+v_{t}\right) \frac{\partial v}{\partial r}\right\}\right] \\
& +\frac{\partial}{\partial z}\left[r\left\{v^{2}-\left(\nu+\nu_{t}\right) \frac{\partial v}{\partial z}\right\}\right] \\
& =-\frac{r}{\rho_{g}} \frac{\partial p}{\partial z}+\frac{\partial}{\partial z}\left\{r\left(\nu+\nu_{t}\right) \frac{\partial v}{\partial z}\right\} \\
& +\frac{\partial}{\partial r}\left\{r\left(\nu+\nu_{t}\right) \frac{\partial u}{\partial z}\right\} \\
& \frac{\partial r u k}{\partial r}+\frac{\partial r v k}{\partial z}=\frac{\partial}{\partial z}\left\{r\left(\nu+\frac{\nu_{t}}{\sigma_{k}}\right) \frac{\partial k}{\partial z}\right\} \\
& +\frac{\partial}{\partial r}\left\{r\left(\nu+\frac{\nu_{t}}{\sigma_{k}}\right) \frac{\partial k}{\partial r}\right\}+r G-r \varepsilon \\
& \frac{\partial r u \varepsilon}{\partial r}+\frac{\partial r v \varepsilon}{\partial z}=\frac{\partial}{\partial z}\left\{r\left(\nu+\frac{\nu_{t}}{\sigma_{\varepsilon}}\right) \frac{\partial \varepsilon}{\partial z}\right\} \\
& +\frac{\partial}{\partial r}\left\{r\left(\nu+\frac{\nu_{t}}{\sigma_{\varepsilon}}\right) \frac{\partial \varepsilon}{\partial r}\right\}+C_{\varepsilon 1} f_{1} r \frac{\varepsilon}{k} G
\end{aligned}
$$




$$
-C_{\varepsilon 2} f_{2} r \frac{\varepsilon^{2}}{k}
$$

ここで,

$$
\begin{aligned}
G & =\nu_{t}\left\{2\left(\frac{\partial u}{\partial r}\right)^{2}+2\left(\frac{\partial v}{\partial z}\right)^{2}\right. \\
& \left.+\left(\frac{\partial u}{\partial z}+\frac{\partial v}{\partial r}\right)^{2}+2\left(\frac{u}{r}\right)^{2}\right\} \\
\nu_{t} & =C_{\mu} f_{\mu} \frac{k^{2}}{\varepsilon}
\end{aligned}
$$

ただし, $u, v$ は $r, z$ 方向の速度, $p$ は圧力, $\rho_{g}$ は気体 の密度, $\nu, \nu_{t}$ はそれぞれ層流の動粘性係数, 乱流の渦 動粘性係数, $f_{\mu}, f_{1}, f_{2}$ はモデル関数, $C_{\mu}, C_{\varepsilon 1}, C_{\varepsilon 2}, \sigma_{k}$, $\sigma_{\varepsilon}$ はモデル定数である.

$2 \cdot 3$ 計算手順 解析にあたっては, スタッガー ド格子を採用し, 各速度成分 $u, v$ をコントロールボ リュームの検査面上で, 他のスカラ量 $p, k, \varepsilon$ はコン トロールボリュームの中心で定義し, 解析はSIMPLLE 法で行う.

境界条件として，次式を用いる。 $r=0$ の対称軸上

$$
\frac{\partial v}{\partial r}=\frac{\partial k}{\partial r}=\frac{\partial \varepsilon}{\partial r}=0
$$

円管壁 $(r=0.5 d n)$

$$
\begin{aligned}
& \frac{v_{1}}{v_{\tau}}=2.5 \log y_{1}{ }^{+}+5.5 \\
& k=\frac{u_{\tau}{ }^{2}}{0.3}, \quad \varepsilon=\frac{u_{\tau}{ }^{3}}{\varkappa y_{1}}
\end{aligned}
$$

ただし，

\section{$u_{\tau}:$ 摩擦速度}

$\varkappa=0.41$ : カルマン定数

円板上 $(z=0, H)$

$$
u=0, k=0, \varepsilon=\frac{2 \nu k_{1}}{y_{1}^{2}}
$$

ここで, $k_{1}, y_{1}$ は壁面から第 1 点めの值である。なお, $\mathrm{AKN}$ モデルを適用するときは, 円板上の $y_{1}$ は $y^{*}<1$ となるように設定する。流出部は自由流出とし，流入 部の円管入口の速度分布に $1 / 7$ 乗則を与え, 円管長さ は $10 d n$ とする. 計算は, 代表長さを $d n$, 代表速度を $v_{a}, R e=v_{a} d n / \nu$ として無次元化して実施する.

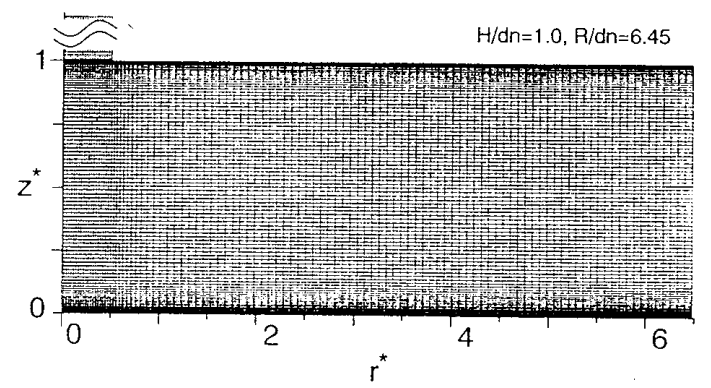

Fig. 2 Grid system
$H / d n=1.0, R / d n\left(=R^{*}\right)=6.45$ の場合について計算 算メッシュの一例を図 2 に示す。 $r$ 方向に $105, z$ 方 向に 143 メッシュであるが，この場合で収束回数は約 20000 回である. Re 数は実験条件に近い 50000 で解 析を行った.

\section{3. 解析結果と実験との比較}

$3 \cdot 1$ モデル定数の検討 図 3 は, $H=d n=31$ $\mathrm{mm}, v_{a}=25 \mathrm{~m} / \mathrm{s}$ の場合について, $z=1 \mathrm{~mm}$ における $u$ の半径方向分布を示している．従来の解析と実験 結果を比較すると, 実験值では $r / d n\left(=r^{*}\right)=4.3$ 付近 で急にこう配が変化し下方円板近傍の流れの状態が変 化しているが, High モデルによる解析では下方円板 近傍の流れを模擬できていない. また，表 1 の定数を もつ AKN モデルでは流れの状態が変化する位置は 見られるが, 実験結果と比べると流れの状態が変化す る位置を過少評価している.

そこで, 実験場を模擬させるために

\begin{tabular}{|c|c|c|c|c|c|}
\hline Model & $\mathrm{C}_{\mu}$ & $\mathrm{C}_{\varepsilon 1}$ & $\mathrm{C}_{\varepsilon} 2$ & $\sigma_{\mathrm{k}}$ & 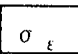 \\
\hline AKN & $\begin{array}{c}\mu \\
0.09 \\
\end{array}$ & 1.50 & 1.90 & 1.40 & 1.40 \\
\hline \begin{tabular}{|l} 
Case 1 \\
\end{tabular} & 0.09 & 1.60 & 1.95 & 1.60 & 1.60 \\
\hline Case 2 & 0.09 & 1.70 & 2.00 & 1.90 & 1.90 \\
\hline \multicolumn{6}{|c|}{$\begin{array}{l}f_{1}=1.0, \cdot R_{t}=\mathrm{k}^{2} /\left(\begin{array}{ll}\nu \varepsilon\end{array}\right) \\
f_{2}=\left\{1-\exp \left(-y^{*} / 3.1\right)\right\}^{2} \times\left[1-0.3 \exp \left\{-\left(R_{t} / 6.5\right)^{2}\right\}\right]\end{array}$} \\
\hline
\end{tabular}
$C_{\varepsilon 1}$ を大きくし，次の関係式(6)を満足するようにモデ ル定数を決めて解析を行う。

$$
C_{\varepsilon 1}=C_{\varepsilon 2}-\frac{\varkappa^{2}}{\sigma_{\varepsilon} \sqrt{C_{\mu}}}, \sigma_{\varepsilon}=\sigma_{\kappa}
$$

その結果, 表 1 のモデル定数を使用することで, $3 \cdot 2$ 節で述べるように下方円板近傍の流れの状態が変化す る位置や他の実験結果ともよい一致が見られ，実験場

Table 1 Constants for AKN and the present models

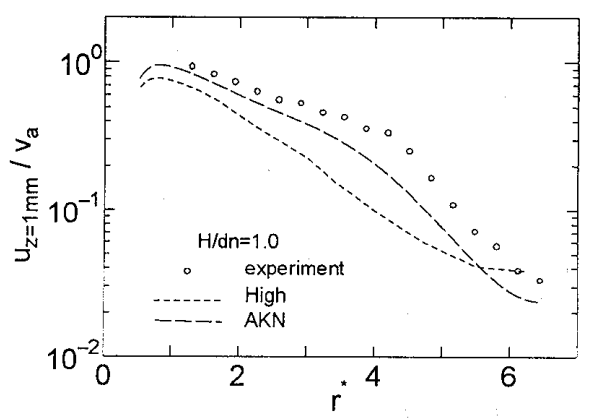

Fig. 3 Distribution of radial velocity near lower disk for High and AKN models 


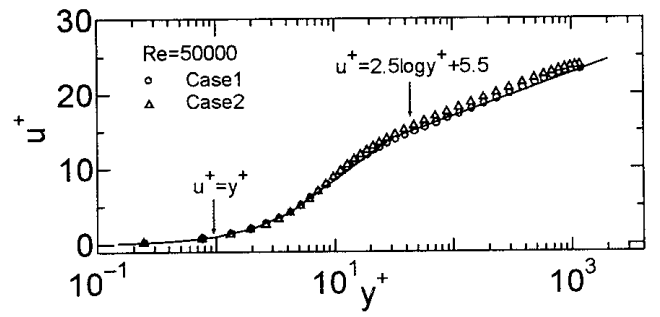

Fig. 4 Velocity profiles in pipe flow
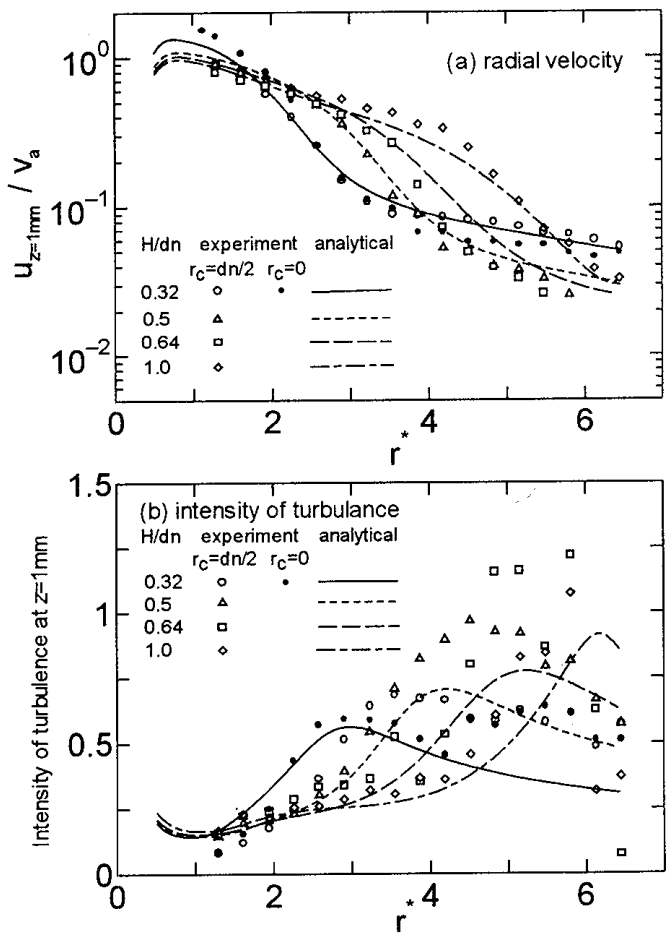

Fig. 5 Distribution of radial velocity and intensity of turbulence on lower disk

をよく模擬することができた。なお，解析は $H / d n=$ 1.0 の場合は Case 1, その他の場合は Case 2 のモデ ル定数を使用して行った。なお，両 Caseのモデル定 数を用いて円管内での発達流れを解析したが, 図 4 に 示すように対数則を満足するものである.

$3 \cdot 2$ 下方円板近傍の流れと圧力 吹出し口の丸 み $r_{c}$ が $d n / 2$ と零の実験值を比較したが，円管出口で 流路の狭まる $H / d n=0.32$ の場合については，吹出し 口丸みの有無 ${ }^{(7)}$ が流れに影響し，中心近傍で分布に顕 著な違いが見られるので以後両方の実験值を併記する が，流路が広がる他の場合はほとんど違いが見られな いので, $r_{c}=d n / 2$ のみ記載する.

図 5(a)に円管内径 $d n=31 \mathrm{~mm}$ の場合で間隔比 $H / d n$ を $0.32 \sim 1.0$, 円板半径は実験と同じ $R / d n=$ 6.45 での $z=1 \mathrm{~mm}$ の半径方向速度分布を示してい る。記号は実験, 線は解析結果を表している.図 5 で $H / d n=0.5$ の場合の解析結果を見ると, $r^{*}=2.6$ 付近
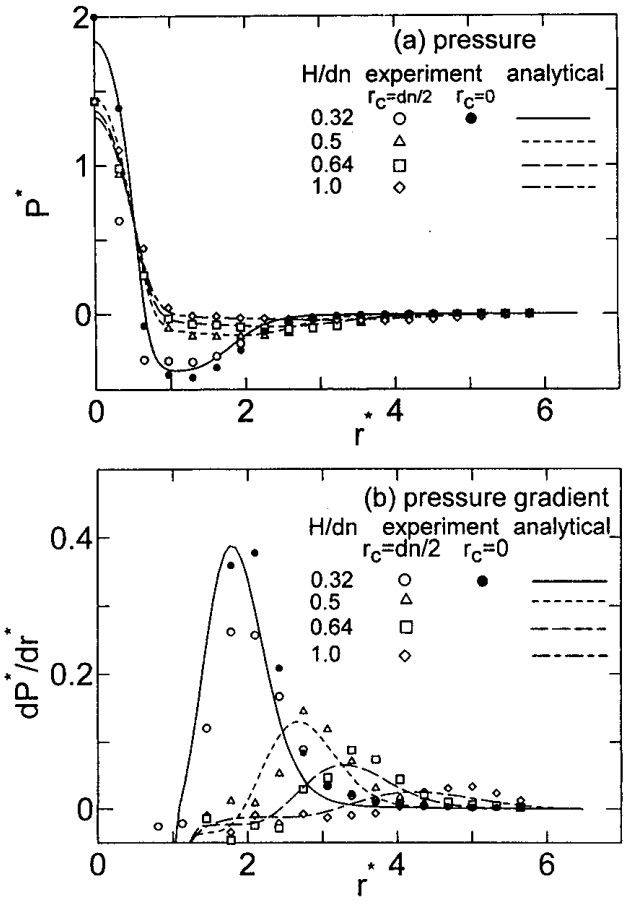

Fig. 6 Distribution of pressure and pressure gradient on lower disk

までは下方円板上に沿って流れるためにほぼ一定こう 配で速度が減少し， $r^{*}=2.6$ 付近で速度の減少のこう 配が急変し，この位置で下方円板近傍の流れの状態が 変化している，そして，再び $r^{*}=4.5$ 付近からこう配 が減少するが，これはこの付近から発達した乱流にな っているためである.この傾向は他の間隔比でも同様 であり，流れの状態が変化する位置は間隔比が大きく なると下流に移動する. $H / d n=0.32, r_{c}=d n / 2(\bigcirc$ 記 号)の中心近傍を除けば, 解析と実験結果はよく合っ ている。

図 5(b)に下方円板近傍 $(z=1 \mathrm{~mm})$ の乱れ強さの半 径方向分布を示している. $H / d n=0.5$ の解析結果を 見ると，乱れの強さは中心近傍で小さく，流れの状態 が変化する $r^{*}=2.6$ 付近で急増し, $r^{*}=4.2$ 付近で最 大値となり，出口に近づくにつれ乱流值が減少してい る。また，実験と解析結果を比較すると，H/dn= $0.32, r_{c}=d n / 2$ を除けば中心近傍の乱れの強さは定 量的にもよく合っており，乱れの強さが急増する位置 もほぼ一致している。しかし，それより下流では測定 值のほうが大きな值を示し，実際の流れのほうが不安 定で乱れが大きい。

$H / d n=0.32, r_{c}=0$ のように円管出口で流路が狭ま る場合の中心近傍での $u$ 值, 乱れ強さは, 流路が広が る他の場合に比べ大きな值を示す特徴がある。

図 6(a) は下方円板上の圧力の半径方向分布であ 
る. $P^{*}$ は大気圧からの差圧 $P$ を $\rho_{g} v_{a}{ }^{2} / 2$ で無次元化 したものである.図6(a)から解析, 実験結果とも下 方円板上の圧力は円管から吹き込まれた流れが衝突す る中心で最大になり, 下方円板に沿って流れ, 圧力が 負圧まで減少し, 半径の増加とともに圧力が回復して いる，また，間隔比が大きくなるに従って，圧力が最 小となる位置は下流に移動し, その最小值は零に近づ く. 実験結果は解析結果と定量的にもよく合ってい る.

急拡大円管内流れでは, 流れ方向の圧力こう配が最 大值を示す位置は流れの再付着点と関係する(8) こと が示されているので, 同様に下方円板上に沿っての圧 カこう配について検討する. 図6(b) は下方円板上に 沿っての $d P^{*} / d r^{*}$ 表す. 図 6(b)の $H / d n=0.5$ の 場合, 中心近傍で圧力こう配は減少するものの, 半径 の増加とともに圧力こう配が増加し始め, $r^{*}=2.7$ 付 近で最大值をとり，再び減少している。この $r^{*}=2.7$ は, 図 5(a)で見られた下方円板近傍の流れの状態が 変化する位置 $r^{*}=2.6$ とほほ一致しているが, 図 10 で後述する流机の上板への再付着点 $r^{*}=3.7$ とは違 う. 他の間隔比でと同様の傾向があり圧力こう配が最 大となる位置は間隔比が大きくなると下流に移動して おり，解析と実験結果は定量的によく合っている.

$3 \cdot 3$ 平行円板間の流れ 図 $7(\mathrm{a}),(\mathrm{b})$ は $H / d n$ が $0.32,1.0$ の場合で, それぞれ円板間の半径方向速 度分布, 流線, 等圧分布を示し, $H / d n=0.32$ は円板半 径を実験と同じ $R^{*}=6.45, H / d n=1.0$ は $R^{*}=15 て ゙$ 解析した結果である. 図の縦方向は横に比へ( $(\mathrm{a})$ の場 合 5 倍, (b) の場合 2.8 倍に拡大してある.

図 7 (a) は円管出口で流路が狭まる $H / d n=0.32$ の 場合である. 図 7(a)の半径方向速度分布と流線から すると，下方円板に衝突した流れは下方円板に沿って 流れ, 図 5(a)の下方円板近傍で流れの状態が変化す る位置 $r^{*}=1.5$ 付近から上方円板に向けての流れが 増加し, $r^{*}=2.5$ 付近で上方円板に再付着し, $r^{*}=4$ 付近で発達した乱流になっている. 次に, 図 7(b)の 円管出口で流路が広がる $H / d n=1.0$ の場合でも速度 分布と流線から下方円板近傍の流れの状態が変化する 位置 $r^{*}=4.3$ 付近で壁に沿った放射状流れから上方 円板に向けての流れが増加し, $r^{*}=7$ 付近で上方円板 に再付着し, $r^{*}=8$ 付近から発達した流れになってい る.

また, $H / d n=0.32$ と 1.0 の流線を比較すると, $H / d n=0.32$ は円板間隔が狭いために下方円板に沿っ て押さえつけるように流れる領域が狭く，すぐに上方 円板に向けての流れが急増する．また，等圧分布を比
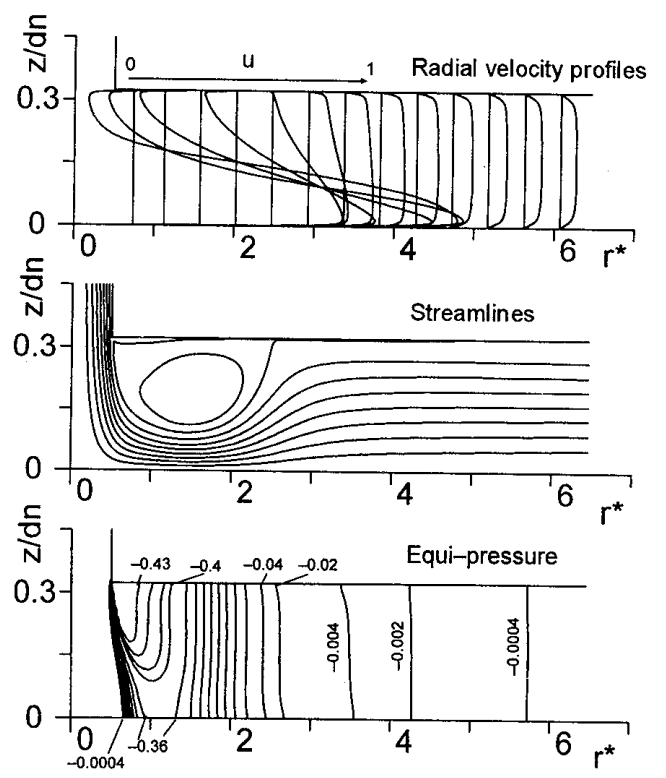

(a) $H / d n=0.32$
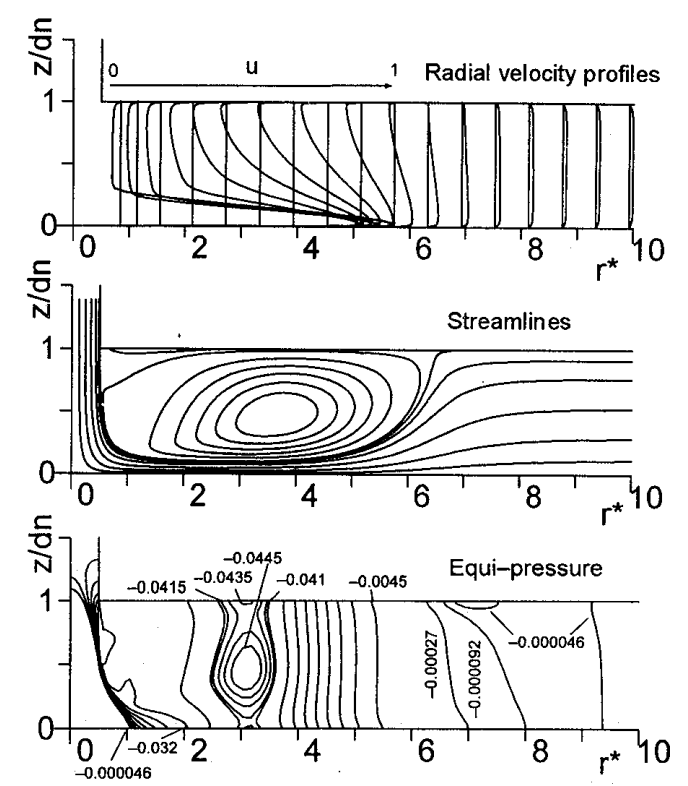

(b) $H / d n=1.0$

Fig. 7 Distribution of radial velocity profiles and streamlines and equi-pressure

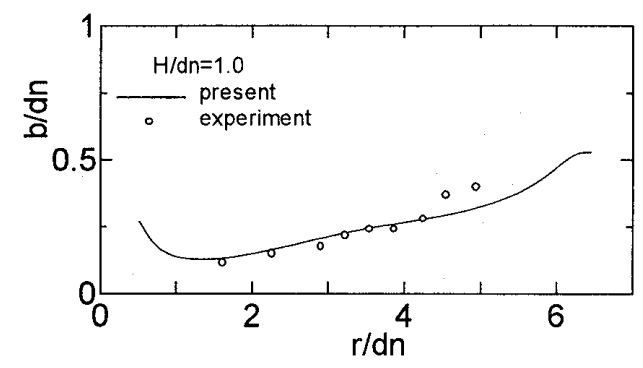

Fig. 8 Relation between $b / d n$ and $r / d n$ 


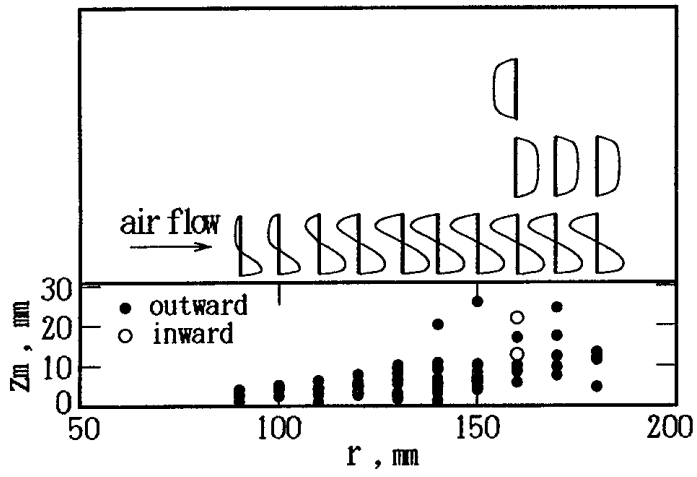

Fig. 9 Relation between $z_{m}$ and $r$

較すると, $H / d n=1.0$ では圧力の低い丸い等圧線 $\left(P^{*}\right.$ $=-0.0445)$ が現れているが, $H / d n=0.32$ では現れ ていない.

$H / d n$ が 0.5 と 0.64 の場合，流線と等圧線の形は円 管出口で流路が広がる $H / d n=1.0$ に近いものである が，下方円板に沿う流れから上方に向けての流れが急 璔する位置は, $H / d n$ が大きくなるにつれて下流に位 置するようになる.

$3 \cdot 4$ 流れの状態が変わる近傍の流れ 図 8 に $H / d n=1.0$ の場合の半值幅 $b$ と半径 $r$ の関係を示し ている. 半值幅は速度 $u$ の $z$ 方向分布で最大速度の 半分の速度になる低壁からの高さである. 図 8 によれ ば $r / d n=4.2$ 付近までは実験值と実線の解析結果は よく合っているが，それより下流では実験の半値幅の ほうが大きくなっている。このことを，スモークワイ ヤ法で $140 \mathrm{~mm}$ 近傍の流れを観察した。半径 $r$ の位 置に垂直にスモークワイヤを設置して, 煙の発生後数 $\mathrm{ms}$ での煙を同じ位置で 10 回撮影して最大速度の現 れる高さ $z_{m}$ を求めた結果, 図 9 を得た。図 90 記 号は最大速度が下流方向に向かっているものを，○記 号は上流へ向かっているものを示している.図 9 より $140 \mathrm{~mm}$ 近傍から $z_{m}$ の大きな值が現れ始め, 非定常 な流れになっていることがわかる。

$3 \cdot 5$ 下方円板近傍の流れと液膜の滞留位置 下 方円板上に液滴を置き気流にさらし，液滴の停止位置 を観察すると液滴体積が $0.1 \mathrm{cc}$ 以上では速度が大き くなると, 液滴の停止位置 (中心側に近い液滴の後端) は，H, $d n$ が決まればほぼ同じ位置となる.この位置 を液膜の滞留位置 $r_{R}$ とする。

図 10 には, 液滴の滞留位置 $r_{R} / d n$, 図 $5(\mathrm{a})$ 力ら得 られる下方円板近傍の流れの状態が変化する位置 $r_{b} / d n$, 図 6(b) 加ら得られる下方円板に沿って圧力 こう配が最大となる位置 $r_{p} / d n$, 解析から得られる上 方円板上の流れの再付着点 $r_{t} / d n$ と間隔比 $H / d n$ の関

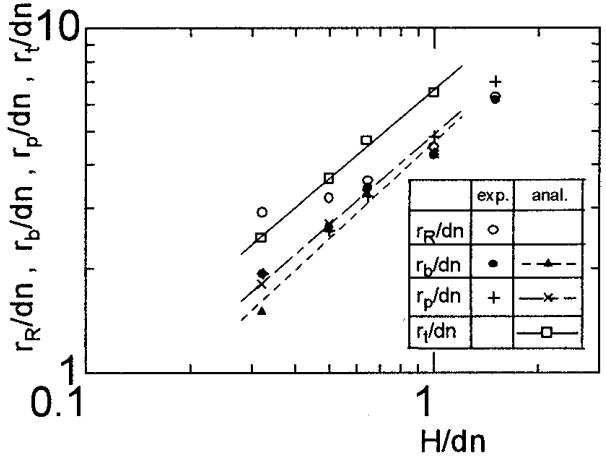

Fig. 10 Relation between $r_{R} / d n, r_{b} / d n, r_{p} / d n, r_{t} / d n$ and $H / d n$

係を実験と解析結果を合せ示してある。図 10 から $H / d n=0.32$ を除いて, 実験, 解析結果ともに液膜の 滞留位置は下方円板近傍の流れの状態が変化する位置 すなわち圧力こう配が最大となる位置とほぼ一致して いる. $H / d n=0.32$ の場合に一致しないのは, 流れの 状態が変わる近傍で円板上の気流速度は吹込み速度近 くの大きな值をもっているので，流れの状態が変化す る位置には滞留できず，風圧による力と表面張力によ る付着力の平衡がとれる位置まで移動し停留するため である。

\section{4. 結言}

円板間に噴霧流を吹き込んだ場合の液膜の帯留位置 と円板間の流れの関係について調べるために，内径 $d n$ の円管から間隔 $H$ の円板間に気流を吹き込む流 れを $H / d n=0.32 \sim 1.0$ の範囲で解析した. 解析と実 験との比較から，以下のことがわかった。

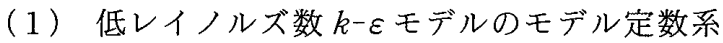
を変更することで，上方円板への再付着を伴う円板間 の複雑な衝突噴流を模擬できる。

（2）下方円板近傍の流れの状態が変化する位置 は，間隔比が大きくなると下流に移動する，その位置 より内側で乱れ強さは小さく，外側では急増する。

（3）下方佃板に沿って圧力こう配が最大となる位 置で上方へ向かう流れが急増する。この位置は下方円 板近傍の流れの状態が変化する位置とほぼ一致する.

（4）液膜の特定滞留位置は，下方円板近傍の流れ の状態が変化する位置とほほ一致する。

（5）流れの状態が変化する位置より下流では，実 際の流れは乱れが大きく非定常な流れである.

卒業研究として実験に参加，協力いただきました石 丸史高, 竹中智也の兩氏に感謝する. 


\section{文献}

（1）村上幸一・砂田崇・植木紀子，機論， 64-632， B(1998)， 2071-2078.

(2) Looney, M. K. and Walsh, J. J., J. Fluid Mech., 147 (1984), 397-429.

(3) Launder, B.E. and Spalding D. B., Comput. Methods Appl. Mech. Eng., 3 (1974), 269-289.
(4) Hosseinalipour, S. M. and Mujumdar, A. S., Numer. Heat Trans. 28, A(1995), 647-666.

（5）明賢國・笠木伸英, 機論, 54-507, B(1988), 3003-3009.

(6) Abe, K., Kondoh, T. and Nagano, Y., Int. J. Heat. Mass Transf., 37 (1994), 139-151.

（7）中林功一・市川武久・森西洋平，機論，62-604，B(1996), 4048-4053.

（8）中西助次 - 桜井元康 - 大坂英雄, 機論, 61-589, B(1995), 3182-3189. 